Original Research

\title{
Nurses Education and Motivation Towards Nursing Documentation
}

\author{
Devi Mediarti' ${ }^{1}$ Rehana Rehana ${ }^{1}$ and Abunyamin Abunyamin ${ }^{2}$ \\ 1 Department of Nursing Polytechnic of Health Palembang, South Sumatra, Indonesia \\ ${ }^{2}$ General Hospital of Palembang BARI, South Sumatra, Indonesia
}

\begin{abstract}
Introduction: Nursing documentation is an integral part that cannot be separated from healthcare as a responsibility and accountability of nurses. High education and motivation are needed to achieve good nursing documentation. The aim of this study was to know the correlation between education and motivation of nurses towards Intensive Care nursing documentation.
\end{abstract}

Methods: The design used was an analytical survey with a cross-sectional approach. The population was nurses in intensive care of Palembang BARI Hospital with as many as 46 nurses and 44 samples obtained with total sampling. Data were collected by questionnaire and observational and were analyzed by Chi-Square. Independent variables are education and motivation of nurses and the dependent variable is nursing documentation.

Results: There was a correlation between education $(p=0.035)$ and motivation $(\mathrm{p}=0.040)$ of nurses towards nursing documentation.

Conclusion: High education and motivation of nurses influenced towards the quality of nursing education. The nursing manager of the hospital is recommended affording the opportunity to support human resources in the hospital, especially for nurses to participate in education, in accordance with the demands of legislation in nursing education, and to organize the training of nursing documentation.

\section{ARTICLE HISTORY}

Received: January 27, 2017

Accepted: May 07, 2018

\section{KEYWORDS}

education; motivation; nurses; nursing documentation

\section{CONTACT}

Devi Mediarti

$\bowtie$ devi@poltekkespalembang.ac.id

$\supseteqq$ Department of Nursing

Polytechnic of Health Palembang,

South Sumatra, Indonesia

Cite this as: Mediarti, D., Rehana, R., \& Abunyamin, A. (2018). Nurses Education and Motivation Towards Nursing Care Documentation. Jurnal Ners, 13(1), 31-35. doi:http://dx.doi.org/10.20473/in.v13i1.3478

\section{INTRODUCTION}

Nursing is a professional service form of basic needs given to individual health and sick conditions, which include physical disorder, psychological and social, in order to achieve the optimal health status. The basic form of fulfillment in individuals can be either improved existing capabilities, prevention, repair and rehabilitation of sick condition as perceived by individuals (Alligood and Tomey, 2006).

Nursing is an integral part that cannot be separated from the overall healthcare effort. Nursing is a study that learns of the cause of the nonfulfillment of basic human needs and makes effort to satisfy such basic human needs in response to the patient (Nursalam, 2008). Professional nursing service is based on nursing as a science process. That is, nursing care as a scientific method of nursing patients' problems - and solving these to improve patient outcomes, which should be documented (Aziz, 2003).
Nursing documentation is an activity of recording, reporting and maintenance that is associated with managing of clients in order to maintain a number of facts from an event in time (Nursalam, 2008). Documentation is evidence of recording and reporting that is owned by nurses in a useful record for the importance of clients, nurses and the medical team in providing health services on the basis of accurate and complete data written as a nurse's responsibility (Suprapto, 2013).

Nursing documentation can be used as the responsibility and accountability of the various possible problems experienced by the patient or client and consists of satisfaction or dissatisfaction of the healthcare provided (Nursalam 2008). Nursing documentation that is timely, accurate and complete is not only important to cover and protect nursing, but it is also important to help patients and clients to get better nursing care (Depkes, 1996). Implementation of nursing documentation is a measure to determine, monitor and conclude 
organized nursing care services in hospitals (Setiadi, 2012).

A study in Indonesia carried out by the Department of Health Mataram West Nusa Tenggara Province in 2013 showed that $71.60 \%$ of nursing documentation was incomplete (Dinas Kesehatan Nusa Tenggara Barat, 2013). Nursing documentation in the South Sumatera province in the inpatients unit of General Hospital of Prabumulih 2012 showed that $65.62 \%$ of nursing documentation was incomplete and $34.37 \%$ of nursing documentation was complete (Zakiroh, 2013).

The phenomenon of incomplete nursing documentation was influenced by many factors, among them individual nurse's characteristics, including education, age, sex, length of service and knowledge. Psychological factors include motivation and organization factors. (Gibson and Ivancevich 2002 cited in Nursalam, 2008). The results of interviews with nurses who served in the intensive care room found that many nurses, while on duty in the room, didn't properly complete the nursing documentation.

Education influenced the implementation of nursing documentation strongly. Nurses with different levels of education will have different quality of documentation, because the higher the level of education, the cognitive abilities and skills will increase as well (Notoatmodjo, 2003).

Performance of hospitals is influenced by its nursing service. Nursing service is highly dependent on nurses' performance, in which the nurses' performances were strongly influenced by the motivation of nurses in nursing documentation. This is in accordance with Davis's opinion (1998 cited in Abdullah, 2012), who said that among the factors which may affect the achievement of nurses' performance in nursing documentation was ability and motivation.

In the results of a preliminary study conducted by researchers, data from General Hospital of Palembang BARI obtained total nurses, dental nurses and midwives throughout hospitalization amounting to 290 people. For the number of nurses who served in the Installation Intensive Care there were 46 people with a total capacity of 15 beds. Incompleteness of medical records of all inpatient status of General Hospital of Palembang BARI in 2013 was $40.03 \%$, in 2014 it was 30\%, and in 2015
31.8\%. (Medical Records of General Hospital of Palembang BARI). Based on the description, the researchers were interested in conducting research with the title "Nurses Education and Motivation Towards Nursing Documentation". The purpose of the study was to know the correlation between education and motivation of nurses towards nursing documentation. The gap analysis of the study could not check the completeness of nursing documents and appropriate nursing language, because the data were collected by questionnaire.

\section{MATERIALS AND METHODS}

This study used analytic survey with cross sectional approaches. The data in this study were obtained using a questionnaire and observation sheets and analyzed by Chi - Square. Total population in this study were all nurses who served in the Installation Intensive Care Unit of General Hospital of Palembang BARI 2016 with as many as 46 nurses and 44 samples obtained with a total sampling technique appropriate to the inclusion criteria. The inclusion criteria were: 1) willing to be a respondent, 2) not in a period of sickness, permit, or suspension, 3) being in place during research.

Independent variables were nurses' education and motivation and the dependent variable was nursing documentation. This study was conducted in the Installation Intensive Care of General Hospital of Palembang BARI between 20 - 25 April 2016.

\section{RESULTS}

The result of this study will be explained based on the information presented in the tables. The result of this study was analyzed by univariate and bivariate using Chi-Square. The result showed Respondent's Characteristics in Installation Intensive Care General Hospital, nurses' education and motivation towards nursing documentation.

Table 1 shows that nursing documentation with good category were 31 respondents (70.5\%), respondents with low education were 30 respondents (68.2\%). Respondents with strength motivation category were 28 (63.6\%

Table 1 Distribution of Respondents' Characteristics in Installation Intensive Care General Hospital of Palembang BARI on April 2016

\begin{tabular}{ccc}
\hline Characteristics & $\mathbf{N}$ & $\mathbf{\%}$ \\
\hline Nursing documentation & & \\
Good & 31 & 70.5 \\
Not Good & 13 & 29.5 \\
\hline Total & 44 & 100 \\
\hline Education & & \\
High (bachelor) & 14 & 31.8 \\
Low (diploma) & 30 & 68.2 \\
\hline Total & 44 & 100 \\
\hline Motivation & & \\
Strength & 28 & 63.6 \\
Weak & 16 & 36.4 \\
\hline Total & 44 & 100 \\
\hline
\end{tabular}


Table 2 Distribution of Nurses' Education towards Nursing Documentation in Installation Intensive Care General Hospital of Palembang BARI on April 2016

\begin{tabular}{|c|c|c|c|c|c|c|}
\hline \multirow{3}{*}{ Education } & \multicolumn{4}{|c|}{ Nursing documentation } & \multirow{3}{*}{ Total } & \multirow{3}{*}{$\%$} \\
\hline & \multicolumn{2}{|c|}{ Good } & \multicolumn{2}{|c|}{ Not Good } & & \\
\hline & $\mathbf{N}$ & $\%$ & $\mathbf{N}$ & $\%$ & & \\
\hline High (bachelor) & 13 & 29.5 & 1 & 4.1 & 14 & 31.8 \\
\hline Low (diploma) & 18 & 40.9 & 12 & 27.3 & 30 & 68.2 \\
\hline Total & 31 & 70.5 & 13 & 29.5 & 44 & 100 \\
\hline \multicolumn{7}{|c|}{$\begin{array}{c}\mathrm{p} \text {-value }=0.035 \\
\mathrm{OR}=8.667\end{array}$} \\
\hline
\end{tabular}

Table 3 Distribution of Nurses' Motivation towards Nursing Documentation in Installation Intensive Care General Hospital of Palembang BARI on April 2016

\begin{tabular}{|c|c|c|c|c|c|c|}
\hline \multirow{3}{*}{ Motivation } & \multicolumn{4}{|c|}{ Nursing documentation } & \multirow{3}{*}{ Total } & \multirow{3}{*}{$\%$} \\
\hline & \multicolumn{2}{|c|}{ Good } & \multicolumn{2}{|c|}{ Not Good } & & \\
\hline & $\mathbf{N}$ & $\%$ & $\mathbf{N}$ & $\%$ & & \\
\hline Strength & 23 & 52.3 & 5 & 11.4 & 28 & 63.6 \\
\hline Weak & 8 & 18.2 & 8 & 18.2 & 16 & 36.4 \\
\hline \multirow[t]{2}{*}{ Total } & 31 & 70.5 & 13 & 29.5 & 44 & 100 \\
\hline & \multicolumn{4}{|c|}{$\begin{array}{c}\mathrm{p} \text {-value }=0.040 \\
\text { OR }=4.6\end{array}$} & & \\
\hline
\end{tabular}

Table 2 shows that respondents with higher education (bachelor) undertook good nursing documentation with as many as 13 respondents $(92.9 \%)$ out of 14 respondents, higher if compared with respondents with lower education (diploma), which served in documentation of nursing with as many as 18 respondents (60\%) from 30 respondents. Chi-Square analysis obtained $\mathrm{p}-$ value $0.035<\alpha(0.05)$ which means there was correlation between nurses' education towards nursing documentation. Odds Ratio $(\mathrm{OR})=8.667$, which means chance of nursing with high education is 8.677 times better in documentation of nursing than nurses with low education.

Table 3 shows that respondents with strong motivation during nursing documentation with good category were 23 respondents $(82.1 \%)$. Chi - Square analysis obtained $\mathrm{p}$ - value $0.040<\alpha(0.05)$, which means there was correlation between nurses' motivation towards nursing documentation. Odds Ratio $(\mathrm{OR})=4.600$, which means nurses strong motivation was 4.600 times better in nursing documentation than nurses with weak motivation.

\section{DISCUSSION}

The independent, complex role of a school nurse requires accurate documentation of assessments, interventions and outcomes. Consistent documentation by all school nurses is crucial to study the impact of nursing interventions on student's health and success in school. While standardized nursing languages are available, the actual use of these languages by school nurses is in the infancy stages of implementation. This national survey of school nurses reveals diverse practices in school nursing documentation. The result of study conducted by Kay and Yearous (2011) shows the implementation of Nursing Language (Nanda, NOC, NIC) will allow school nurses to document more consistently, base practice decisions on evidence, and improve the health and academic success of students in schools. It means that, starting from school, nurses must have optimal education of nursing documentation.

Nursing documentation is an important part of clinical documentation. A thorough nursing documentation is a precondition for good patient care and for efficient communication and cooperation within the healthcare professional team (Ammenwerth, et al., 2001). Nursing documentation is an indicator of the performance of nursing while performing nursing care that can be seen from the implementation of nursing documentation. Without nursing documentation, all of the nursing implementation done by nurses has no meaning in terms of responsibility and accountability (Dellefield, 2006). Nursing documentation is one of the efforts required to establish and maintain accountability of nurses and nursing (Webster New World Dictionary cited in Marelli, 2007).

Nursing staff working in long-term institutional care attend to residents with an increasing number of severe physical and cognitive limitations. To exchange information about the health status of these residents, accurate nursing documentation is important to ensure the safety of residents (Saranto and Kinnunen, 2009). The implementation of nursing documentation a measure in determining, monitoring and concluding nursing care service organized by the hospital (Fischbach, 1991 in Setiadi, 2012). Education is greatly influenced the implementation of nursing documentation. Nurses with different levels of education will have different quality of documentation, because the higher the level of education, the cognitive abilities and skills will increase as well (Notoatmodjo, 2003).

Wawan and Dewi (2010) stated that the higher a person's education, the more easily to receive information, so that they can make a decision to do the documentation. Whereas Siagian (2010) states 
that higher education would increase the motivation, desire and intellectual maturity in the application of the complete documentation. Gibson and Ivancevich (1995) state that higher education levels generally lead to someone being more able and willing to accept responsibility. This will affect the completeness of the nursing documentation.

Nursing services are highly dependent on the performance of nurses, which is strongly influenced by the performance of nurse's motivation (Broderic and Coffey 2013). This is in accordance with the opinion of Davis (1997) cited in Abdullah, 2012) who said that the factors that may affect the achievement of the nurses' performance in nursing documentation include capability and motivation.

Nursing documentation requires nurses motivation that comes from the heart, to create nurses' strong motivation, and the need to be aware of the need and importance of nursing documentation (Swanburg, 2000). Proper motivation will encourage the employees to do as much as possible in carrying out their duties because they believe that the success of the organization in achieving the goals and targets of various personal interests of members will be fulfilled also (Siagian, 2010). Ilyas (2001) said that if someone is motivated and concerned they will strive to improve achievement.

The result of this study showed that there was significant correlation between nurses' education towards nursing documentation in Installation Intensive Care General Hospital of Palembang BARI 2016. The result of a study conducted by Pratiwi et al. (2013) regarding the correlation of education levels and long period of works towards the completeness of nursing documentation in General Hospital of Tugumulyo, Tugurejo, Semarang, showed that there was significant correlation between education levels towards the completeness of nursing documentation.

Researchers assumed that the education level of nurses had an important role in quality of nursing documentation as a good or not good indicator of nursing service in hospitals that will improve the quality of the hospital so that appropriate care quality standards will be achieved. The result is that a higher level of a nurse's education will improve the quality of nursing documentation in the nurse's work areas. This is because the level of education will affect the cognitive ability and intellectual maturity and motivation of the nurses (Voyer et al., 2014).

The current study conducted by Tuinman et al. (2017) found inaccuracies in the content and coherence of nursing documentation in long-term institutional care. This may complicate communication between health professionals, data extraction by managers for quality and reimbursement purposes and also jeopardize residents' safety and wellbeing. Taking into account the increasing acuity levels of residents, managers should reconsider whether the available nursing staff and resources are sufficient to provide for accurate nursing documentation. Investments in resources (e.g., time, structured (electronic) careplans) may be required to facilitate accurate documentation. Furthermore, the reasoning skills of nursing staff should be investigated and trained, tailored to their educational background and scope of practice, to ensure that they competently perform their careplanning job responsibilities. Implementation of professional standards in accordance with legal requirements and regular audits may further enhance the quality of nursing documentation.

The result of the study conducted by the researcher showed that there was correlation between nurses' motivation towards nursing documentation in Installation Intensive Care General Hospital of Palembang BARI 2016. The study conducted by Pakudek et al. (2014) about the correlation of nurses' motivation towards nursing documentation in Installation Inpatient C of RSUP Prof. Dr. Kandou Manado, showed that there was significant correlation between nurses' motivation towards nursing documentation. The researcher assumed that the level of nurses' motivation had an important role in quality of nursing documentation, as good or not good indicators of a nurse's service in the hospital, which will improve the quality of the hospital so that appropriate care quality standards will be achieved.

In our opinion, a high acceptance of the nursing process, a careful preparation of predefined care plans (at least partly based on standardized vocabulary), together with elementary measures, such as organizational preparation, good project management, inclusion of future users in the preparation process, and sufficient technical equipment with integration into the hospital information system, are important preconditions for the success of nursing process documentation (Ammenwerth et al., 2001). This confirms the results of other studies. In addition, the nursing terminology and the nursing care plans must be regularly maintained and updated, taking into account the development of skills and experiences of the users (Wang et al., 2011).

As a result, the higher level of a nurse's education will improve the quality of nursing documentation in the nurse's work areas. This is because the level of a nurse's motivation will influence their performance and the motivation to give the nurses a direction of interest in doing their job.

\section{CONCLUSION}

Education and motivation of nurses have significant relationship to the nursing documentation in Hospital Intensive Care Unit. This was due to the high level of education and a strong motivation level which will provide quality nursing care.

The hospital management is expected to provide opportunities and encourage hospital human 
resources, especially for nurses to be able follow appropriate education hierarchically. This is in accordance with the demands of legislation governing nursing education, and it should hold trainings on documentation. Future research is expected to add methodology, sample, variables and other factors related to the nursing documentation in the Installation Intensive Care.

\section{REFERENCES}

Alligood, M. And Tomey, A. (2006). Nursing Theorist and Their Work. 6th ed. ST. Louis: Mosby Elsiver, Inc.

Ammenwerth, E., Kutscha, U., Kutscha A., Mahler, C., Eichstädter, R. and Haux, R. (2001). Nursing process documentation systems in clinical routine-prerequisites and experiences. International Journal of Medical Informatics, 64, pp.187-200.

Aziz, A.A. (2003). Riset Keperawatan dan Teknik Penulisan Ilmiah, Jakarta: Salemba Medika.

Broderic, M. and Coffey, A. (2013). Person-centered care in nursing documentation. International Journal of Older People Nursing, 8, pp.309-318. [online] Available at: http://dx.doi.org/10.1111/opn.12012. (Accessed: August 8, 2016).

Davis, K. (1997). Human Behavior at Work. Organization Behavior. 8th ed. Singapore: Mc. Graw-Hill. International.

Dellefield, M. (2006). Interdisciplinary care planning and the written care plan in nursing homes: a critical review. Gerontologist, 46, pp.128-133.

Depkes, R. (1996). Konsep dan Proses Keperawatan, Jakarta: Departemen Kesehatan.

Fischbach, F. (1991). Documenting Care Communication, The Nursing Process and Documentation Standards, Philadelphia: F.A Davis Company.

Gibson, J. and Ivancevich, J. (1995). Organisasi, Perilaku, Struktur, Proses, Jakarta: Binarupa Aksara.

Ilyas, Y. (2001). Kinerja: Teori, Penilaian, dan Penelitiann, Depok: Pusat Kajian Ekonomi Kesehatan FKM UI.

Kay, S. and Yearous, G. (2011). School nursing documentation: knowledge, attitude, and barriers to using standardized nursing languages and current practices. Lowa Research Online. [online] Available at: htp://ir.uiowa.edu/etd/3411 (Accessed: August 8, 2016).

Kelengkapan Pengisian Dokumentasi Pengkajian Asuhan Keperawatan di RSUD Tugurejo Semarang. STIKES Telogorejo2.
Marelli, M. (2007). Dokumentasi Keperawatan 3rd ed., Jakarta: EGC.

Notoatmodjo, S. (2003). Pendidikan dan Perilaku Kesehatan, Jakarta: Rineka Cipta.

Nursalam, N. (2008). Pendidikan Dalam Keperawatan, Jakarta: Salemba Medika.

Pakudek, K.H., Robot, F.J. and Hamel, R. S. (2014). Hubungan Motivasi Perawat dengan Pelaksanaan Dokumentasi Keperawatan di Instalasi Rawat Inap C RSUP Prof Dr. Kandou Manado. Jurnal Keperawatan, 2(2).

Pratiwi, P.P., Suryani, M. and Sayono, (2013). Hubungan Tingkat Pendidikan dan Lama Kerja dengan

Saranto, K. and Kinnunen, U., (2009). Evaluating nursing documentation e research designs and methods: systematic review. J Adv Nurs, 65, pp.464-476.

Setiadi, (2012). Konsep dan Penulisan Dokumentasi Keperawatan: Teori dan Praktik, Yogyakarta: Graha Ilmu.

Siagian, S.P. (2010). Teori Motivasi dan Aplikasinya, Jakarta: Rineka Cipta.

Suprapto, (2013). Dokumentasi Keperawatan, Yogyakarta: Nuha Medika.

Swanburg, R. 2000. Pengantar Kepemimpinan dan Manajemen Keperawatan, Jakarta: EGC.

Tuinman, A., de Greef, M.H.G., Krijnen, W.P., Paans, W. and Roodbol, P.F. (2017). Accuracy of documentation in the nursing care plan in longterm institutional care. Geriatric Nursing, 20, pp.1-6. [online] Available at: http://dx.doi.org/10.1016/i.gerinurse.2017.04.0 $\underline{07}$ (Accessed: August 8, 2016).

Voyer, P., McCusker, J. and Cole, M. (2014). Nursing documentation in long-term care settings: new empirical evidence demands changes be made. Clinical Nursing Research, 23, pp.442-461. [online] Available at: http://dx.doi.org/10.1177/1054773813475809 (Accessed: August 8, 2016).

Wang, N., Hailey, D. and Yu, P. (2011). Quality of nursing documentation and approaches to its evaluation: a mixed-method systematic review. Journal of Advanced Nursing, 67 (9), pp.18581857. [online] Available at: http://dx.doi.org/10.1111/j.13652648.2011.05634.x (Accessed: August 8, 2016).

Wawan, A. and Dewi, M. (2010). Teori dan Pengukuran Pengetahuan, Yogyakarta: Nuha Medika.

Zakiroh, N. (2013). hubungan Antara Asuhan Keperawatan di Instalasi Rawat Inap Rumah Sakit Muhammadiyah Palembang. STIKES Muhammadiyah Palembang. 